Bangladesh Journal of Bioethics 2010; 1(2):11-19

\title{
ETHICAL PERCEPTION OF TISSUE BANKING IN BANGLADESH
}

\section{Hasan M. Zahid*, Kanchan Chakma, Mamun Miah and Azizun Nessa}

Tissue Banking and Biomaterial Research Unit, Atomic Energy Research Establishment (AERE), GPO Box-3787, Dhaka-1000, Bangladesh

Bangladesh Atomic Energy Commission has initiated the processing of human tissue for utilization in reconstructive surgery as allograft in cooperation with the International Atomic Energy Agency (IAEA). Tissue donation and grafting has comprehensive and versatile role in the health care sector. IAEA programmes to develop a series of tissue banks throughout South East Asia by having great significance for improving basic health care in other developing countries. Utilization of human tissues has been practicing in many countries and it has a long history. Bangladesh is somewhat new in the field of tissue banking activities to treat degenerative bone diseases, congenital deformities, bone fractures, gap non-union from traumatic accidents, dental defects, different type of burns, acid violence, leprotic ulcer, bedsore, traumatic open wound, diabetic wound etc. Several hospitals and clinics throughout the country are currently involved in tissue procurement and grafting though some of intricate ethical problems (ideological, cultural, psychological, and religious) and conflicts stay behind this field. For ethical and legal concern, the healthcare personnel have been working under the law of "Human Organ / Tissue Donation and Transplantation Act", as the National Parliament of the People's Republic of Bangladesh has approved the declaration on $13^{\text {th }}$ April-1999 requiring consent from the donor or next of kins. Before considering the legal and ethical questions associated with tissue banks, several functions must be identified and followed: improvement of the patient care, elimination of the trauma and morbidity associated with secondary surgical procedures, reduction of the prolonged hospital stays and medical costs etc. Although ethics, moral principles, and legal aspects are practicing within some degree of people, it should disseminate enormously to the general public of the country as they could be more aware and interested to tissue donation thereby more people will contribute to alleviate sufferings and more lives will save.

Key Words: amniotic membrane, bone, confidentiality, informed consent, organizational policies, standards, and tissue banking.

* Correspondence: Hasan M. Zahid, Scientific Officer, Tissue Banking and Biomaterial Research Unit, Bangladesh Atomic Energy Commission, GPO Box-3787, Dhaka-1000, Bangladesh, E-mail: zahid_bmb@yahoo.com

\section{INTRODUCTION}

Radiation Sterilized human amniotic membrane and bone allografts have been using successfully in different types of clinical disorders and injuries in Bangladesh. To rehabilitate and treat these sorts of health problems in our country, such as different type of burns, acid violence, leprotic ulcer, bed-sore, traumatic open wound, diabetic wound, degenerative bone diseases, congenital deformities, bone fractures, gap non-union from traumatic accidents, oral and maxillofacial defects "Tissue Banking and Biomaterial Research Unit" of Bangladesh Atomic Energy Commission regularly providing radiation sterilized amnion membrane and 
bone allografts to different hospitals and clinics throughout the country. At present, 109 hospitals and clinics and more than 300 surgeons \& physicians are involved with this unit through utilization of radiation sterilized tissue allografts. By following scientific procedure, gamma radiation $\left(\mathrm{Co}^{60}\right)$ is used for tissue graft sterilization. This unit is also undertaken research activities on both the fundamental and applied / clinical areas of tissue banking.
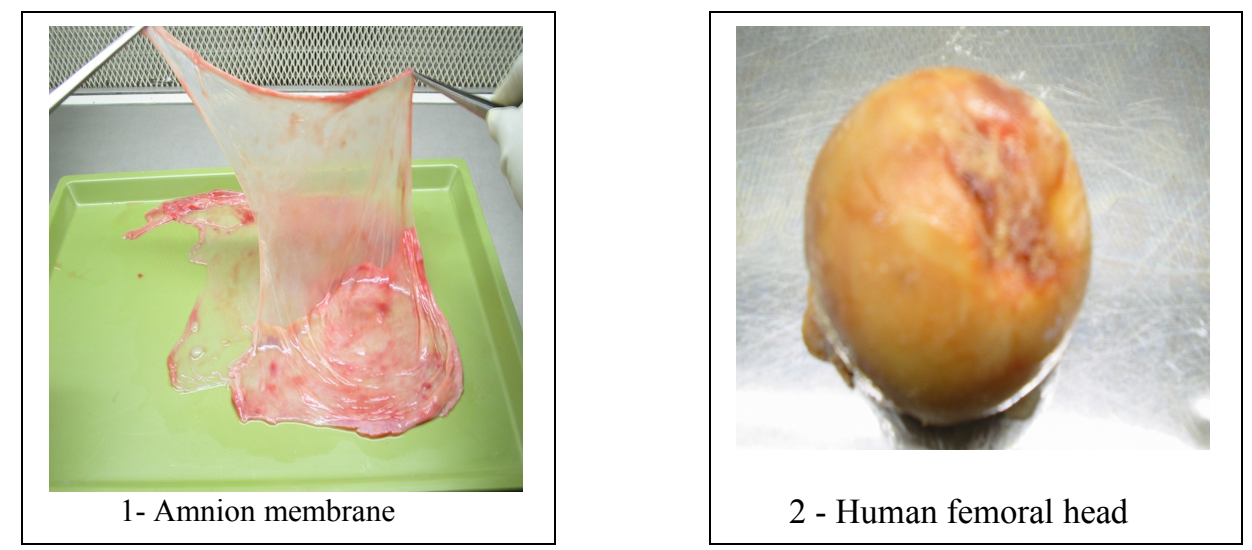

Photograph $1 \& 2$ represent processing and use of human tissue (amniotic membrane \& bone).

Tissue banking research progressively more is accomplished in partnership between the forprofit and not-for-profit spheres, lifting up many ethical considerations (1). In part, this change can be attributed to the growing sophistication of genomic technology and, in particular, the new interest it has fueled in human tissue (2). In addition, tissue banks in the non-profit sector are often supported by the pharmaceutical and biotech industries that help fund academic research and rely on human biological samples recovered and banked by these institutions (3). Some contend that the current system of safeguards (at least in the US) will become increasingly obsolete in protecting tissue donors; others point to a variety of cultural, organizational, and professional issues that question the ethical appropriateness of for-profit tissue banks and academic-industry relationships (4). In these regards, various governments, non-governmental organizations, and other institutions have been planning and promulgating policies to regulate tissue banks and their relationships with industry. These policies represent the consensus of private associations (such as the American Association of Tissue Banks), reflect the national policies of certain governments (such as Spain), and are the products of various international bodies (such as the European Union). Thus, these policies are broad in scope; we have not surveyed the institutional policies of individual banks, academic medical centers, or other institutions. Moreover, the enforcement mechanisms will similarly reflect the authority of the bodies that produce such policies. For instance, a private association will have relatively little authority to sanction individual banks for violations of certain policies; on the other hand, governments will have appropriate enforcement mechanisms to ensure compliance (although resources to achieve such compliance will vary from country to country).

Wherever tissues are removed from human beings, and possibly transplanted into other human beings, the activities involved in the collection and use of such tissues are subject to ethical requirements intended to safeguard respect for human beings, their dignity and 
autonomy, and for the common good. As the issue of safety is vital, the protection must extend to tissue donors and recipients, and to all health care professionals - whose work involves collecting, manipulating and using human tissues.

\section{LAWS AND REGULATIONS: BANGLADESH}

1. A bill on "Human Organ/Tissue Donation and Transplantation Act" has been passed by the National Parliament of the people's Republic of Bangladesh on 13th April 1999 (5/1999) requiring consent from the donor or next of kin. (5/1999)

2. A bill on "Safe Blood Transfusion Act, 2002" (12/2002) has been passed by the national parliament of the people's Republic of Bangladesh making serological screening mandatory for tissue/ organ donation. (12/2002)

\section{VIABILITY OF HUMAN TISSUES}

A number of potential benefits stem from the commercialization of human tissues. For industry, the likelihood of profit based on medical products derived from human tissues is an effective incentive to invest in related academic research. With the judicious use of patents and other forms of intellectual property rights, industry has added reason to support cuttingedge and sometimes financially risky academic research involving human tissues. From the perspective of academic centers, the infusion of capital by industry can help to fund innovative research and support the training of researchers. Perhaps the most important benefit associated with the commercialization of human tissue comes from the successful interchange between the two spheres, toward a more efficient transmission of knowledge from academic based tissue banks to industry, facilitating the development and delivery of medical products to the public. There is, however, a potential downside to the commercialization of human tissues. Specifically, the growth of for-profit tissue banks and augmented academic-industry partnerships increase the likelihood of conflicts of interests. For example, financial incentives to academic researchers (e.g., stock options and royalties) could undermine scientific standards of integrity by promoting secrecy, data hoarding, and even the manipulation of research outcomes. If this occurs, the commercialization of human tissues could have the unintended consequence of compromising human tissue research and subordinating the health of the public to profit maximization. Beyond concerns regarding conflicts of interests, the commercialization of human tissues also raises a host of broader social, cultural, religious, and psychological issues on the meanings we assign to the human body and, in particular, on how we treat it during life and after death (5). Table 1 and 2 represent non-profitable collection, processing and supply of amniotic membrane and bone allografts those were being prepared by the Tissue Banking and Biomaterial Research Unit of Bangladesh Atomic Energy Commission in 2008. These grafts were used to treat different types of diseases throughout Bangladesh. 
Bangladesh Journal of Bioethics 2010; 1(2):11-19

Table- 1

\begin{tabular}{|c|c|c|c|c|c|c|}
\hline $\begin{array}{l}\text { Type of } \\
\text { tissue }\end{array}$ & \multicolumn{2}{|c|}{ Number } & $\begin{array}{l}\text { Number of grafts } \\
\text { prepared }\end{array}$ & $\begin{array}{l}\text { Number of } \\
\text { grafts supplied }\end{array}$ & \multicolumn{2}{|l|}{ Patients treated } \\
\hline \multirow{12}{*}{$\begin{array}{l}\text { Human } \\
\text { amniotic } \\
\text { membrane }\end{array}$} & \multirow{12}{*}{\multicolumn{2}{|c|}{$\begin{array}{l}389 \\
\text { (Foetal sacs./ } \\
\text { placenta) }\end{array}$}} & \multirow{6}{*}{1901 pieces } & \multirow{6}{*}{1751 pieces } & Heat burn & 146 \\
\hline & & & & & Acid burn & 05 \\
\hline & & & & & $\begin{array}{l}\text { Diabetic wound/ } \\
\text { diabetic foot ulcer }\end{array}$ & 01 \\
\hline & & & & & Leprotic ulcer & 03 \\
\hline & & & & & $\begin{array}{l}\text { Abdominal wall } \\
\text { reconstruction }\end{array}$ & 04 \\
\hline & & & & & Total & 159 \\
\hline & & & & & $\begin{array}{l}\text { Chemical (acid) burn } \\
\text { (corneal surface Rt.) }\end{array}$ & 01 \\
\hline & & & 154 pieces & 136 pieces & Chemical (lime) burn & 01 \\
\hline & & & (Eye graft) & (Eye graft) & Pterigium removal site & 05 \\
\hline & & & & & Peripheral corneal ulcer & 01 \\
\hline & & & & & Orbit reconstruction & 01 \\
\hline & & & & & Tot & 09 \\
\hline
\end{tabular}

Preparation and uses of Human amniotic membrane (in 2008)

Table- 2

\begin{tabular}{|c|c|c|c|c|c|}
\hline Type of & & Number of grafts & Number of grafts & \multicolumn{2}{|l|}{ Patients treated } \\
\hline \multirow{9}{*}{$\begin{array}{l}\text { Human } \\
\text { femoral } \\
\text { head }\end{array}$} & \multirow{9}{*}{423} & \multirow{9}{*}{$\begin{array}{l}3810 \\
\text { (chips/segments) }\end{array}$} & \multirow{9}{*}{$\begin{array}{c}3172 \\
\text { (chips/segments) }\end{array}$} & Giant cell tumor (GCT) & 76 \\
\hline & & & & $\begin{array}{l}\text { Aneuroysmal bone cyst } \\
\text { (ABC) }\end{array}$ & 18 \\
\hline & & & & Simple bone cyst (SBC) & 13 \\
\hline & & & & Fibrous dysplasia (FD) & 19 \\
\hline & & & & Gap non-union & 27 \\
\hline & & & & Bone fracture & 66 \\
\hline & & & & Spinal fusion/scoliosis & 02 \\
\hline & & & & $\begin{array}{l}\text { Osteomyelitis \& other } \\
\text { bone defects. }\end{array}$ & 03 \\
\hline & & & & Total & 29 \\
\hline
\end{tabular}

Preparation and uses of Human femoral head (in 2008) 
Many people conceptualize the transfer of human organs and tissues during life or after death as a gift motivated by altruistic feelings, not economic incentives. U.S. federal law prohibits the buying and selling of human organs, it does allow fees for the recovering, processing and transporting of human tissue (6). The exportation of blood from the U.S. alone is a multibillion dollar industry (7); other human tissues such as hair and corneas play an important role in commerce. The American Association of Tissue Banks (AATB) (8) provides even less guidance, as it has no explicit statement, general or specific, about the commercial aspects of tissue banking. Unlike the BATB and the AATB, two reports from the Health and Human Services/Food and Drug Administration/Office of Inspector General (HHS/FDA/OIG) provide guidelines that address some of the commercial aspects of tissue banking (9).

\section{CONFIDENTIALITY}

Confidentiality, which refers to the promise not to disclose information that the donor does not want disclosed, is treated by all the organizations and countries that were surveyed as an important value to be protected. Different levels exist among methods to curtail breaches of confidentiality. Commentators have outlined a useful taxonomy of:

- Identified: The tissue source is known and the individual's identity is tied to the sample.

- Identifiable: The tissue source is tied to the specimen through the use of a link (e.g., a code number), but the identity of the source is not directly known without tracing the link.

- Anonymized: The tissue source's identity is irrevocably unlinked from the specimen, so that the individual's identity cannot be discerned (i.e., the tissue is not identifiable).

- Anonymous: The tissue source's identity is never known, since the specimen is collected with no identifiers at all (i.e., the sample is unidentified) (10).

\section{PROTECTION OF THE DONOR AND RECIPIENT}

With regard to the removal of tissues, the main ethical principles from the donor's point of views are the respect for the human body, even after the person's death; for the autonomy of the donor; thus, tissue may not be removed whenever the person refuses. For deceased persons, this implies that tissues may not be removed if the person refused consent during her/his lifetime. It is required to protect vulnerable people, namely people unable to give consent; respect for private life and medical confidentiality, which is a fundamental right; the right to prior information on the conditions of removal and the expected use of the tissues; the right not to be subjected to unfair discrimination, which could result from the revelation of data collected from the donor, or the family, to third parties (e.g. employers and insurance companies).

The main principles affecting recipients of allografts are the respect for the autonomy of the person concerned, which requires clear information on the risks and advantages of the proposed transplant; respect for private life and medical confidentiality, which applies to all medical treatment; the right to safety, which requires prior verification of the quality and safety of the tissue to be transplanted with regard to the risk of transmission of infectious diseases, neoplasms and immunological diseases; the right of patients to have fair access to the therapeutic possibilities offered by the transplantation of human tissues; the effectiveness of this right depends partly on the greater or lesser availability of tissues. 
Bangladesh Journal of Bioethics 2010; 1(2):11-19

\section{INFORMED CONSENT}

Informed consent serves as a safeguard for individuals' rights and welfare, by providing them the opportunity to understand an intervention, its scope, and its implications, before they decide whether to agree to it. In the context of this discussion, the intervention is the collection of tissue samples by a tissue storage facility for the purpose of research.

What should the informed consent process for the collection of tissue samples include? This question pertains to tissue samples that have yet to be collected. It needs to be distinguished from a related but separate matter: What should be done with collected tissue samples that were obtained with informed consent that would not meet current standards? The latter question is not directly addressed in this paper, which concerns itself with the collection of tissue, except to say that the more rigorous alternative of going back to donors or donors' families to obtain consent for unanticipated uses is the gold standard: it provides assurance that the donor's wishes will be respected. Unless donors (or their families) understand the specific nature of a research protocol in which they are enrolling, they neither can assess adequately whether participation in the overall investigation is consistent with their values, nor freely and deliberately refuse participation in certain aspects of a study.

\section{ROLE AND RESPONSIBILITIES OF TISSUE BANK}

Activities of procurement, which are non-commercial, as well as activities carried out by tissue banks require an authorisation. This authorisation must be subject to compliance with basic ethical principles and with health safety standards, which themselves are an ethical imperative. Safety rules must be uniform throughout the country. Tissue banks have an eminent responsibility to monitor implementation of these rules and principles. They should refuse to accept tissues the procurement of which does not satisfy ethical principles and safety rules. Tissue banks also have specific responsibilities as regards protecting the confidentiality of the personal data they keep on donors and their families. In view of their responsibility for the quality and safety of the tissues they provide to third parties, banks should be obliged to keep a register of the tissues stored and distributed. This register should be available for presentation to the national inspectorates at all times.
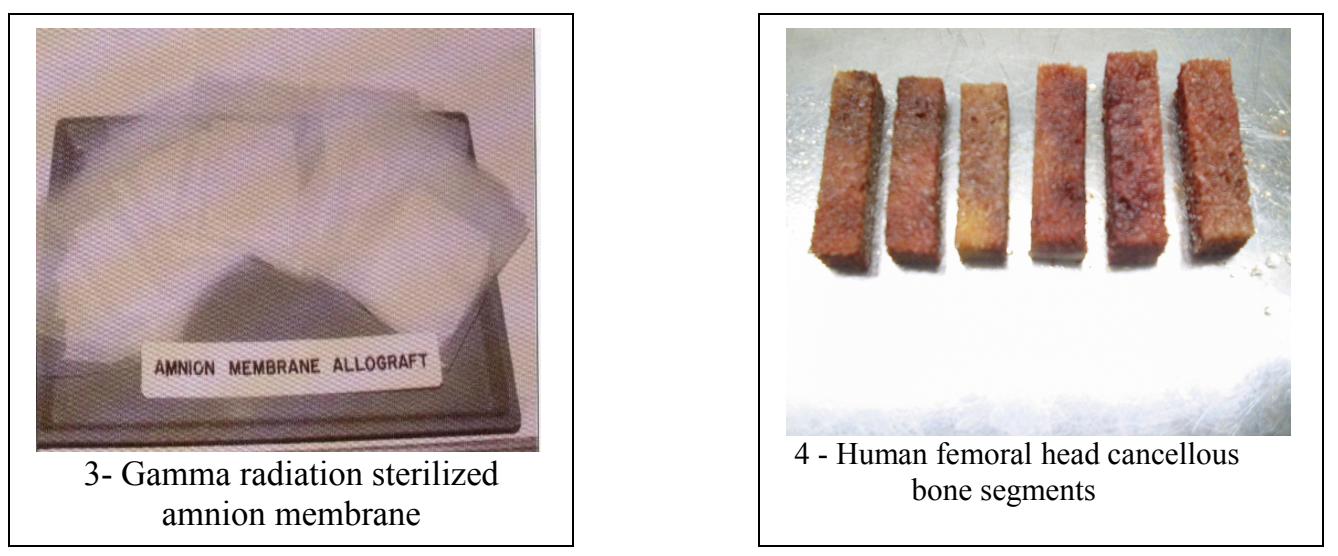

Photograph $3 \& 4$ represent the processing of amniotic membrane and bone allografts 


\section{FINDINGS FROM RESEARCH ON TISSUE SAMPLES}

It seems best to discuss at the time consent is sought what will later become of information derived from tissue samples. Two major questions arise with regard to findings. Should they be communicated to the donor (or donor's family)? It may be feasible for the facility to contact the donor (or donor's family) with findings that pertain to them, where the samples were identified. So, it is important for potential donors to contemplate whether this is information they would welcome - and in what detail. Knowledge regarding the risks and benefits associated with learning this sort of information - and what it means that it is familial in nature - can help inform this decision. Where tissue samples are anonymized, general findings are the only kind of information the donor (or donor's family) can consent to receive. The other question that arises from the findings is whether the donor (or donor's family) can share in any profits from products, tests, or discoveries that result from the research. While it seems easiest to preclude this sort of sharing, some organizations allow it. Details of how the donor (or donor's family) will benefit are worked out during the consent process. In these latter cases, it is helpful to determine conditions as part of the informed consent process. Several of the European policies rely on notions of presumed consent for organ and tissue retrieval from deceased individuals (Belgium, European Commission, France, and Spain), while British and American policies stress informed consent with different levels of specificity.

\section{COLLECTED TISSUE SAMPLES: ANTICIPATED USES}

Tissue storage facilities receive donations and make samples available to investigators for research purposes. The donor (or donor's family) may want to know whether the facility has ties with commercial, as well as non-commercial, companies. Does it stand to benefit financially? What criteria does the facility use to determine to whom to provide tissue samples? The party making the donation may be able to limit or suggest to what sort of company the samples should be provided. Along similar lines, the donor (or donor's family) might have the opportunity to specify or recommend toward what type of research the tissue may be used. The risk is that people with insufficient scientific grounding will participate in complex research decisions and that they may request limits that are difficult, unfeasible, or impossible to implement.
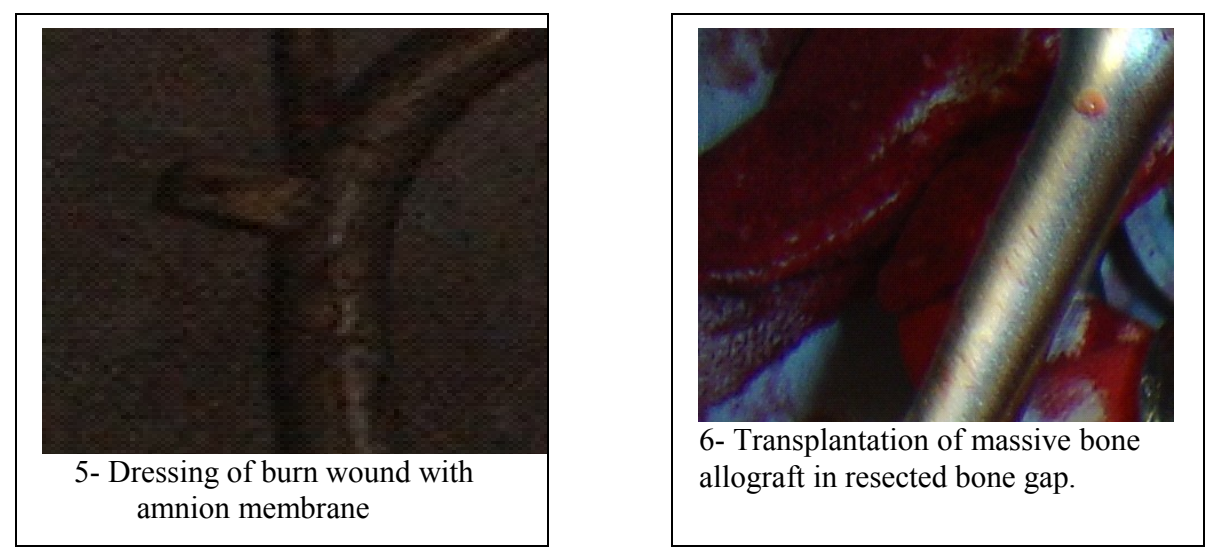
Photograph $5 \& 6$ represent the use of amniotic membrane and bone allografts to rehabilitate burn and bone injured patient

DISCUSSION

In Bangladesh, we believe that tissue banks systematically should consider the following requirements: First, each tissue bank should have a mission statement, against which it can assess the merits of proposed uses of donated tissue. Developing such a document will serve to provide a definition of what constitutes high quality research in the eyes of the particular bank. Second, financial conflicts of interest can be addressed, in part, by ensuring that those making tissue allocation decisions do not have personal financial stakes in potential recipient organizations, or by sharply circumscribing such relationships.

Third, tissue banks should be explicit about their standards of "confidentiality:" Are tissues identified, identifiable, anonymized, or anonymous? They should develop adequate methods to limit breaches of confidentiality, which are made known. Tissue banking guidelines and policies need be specific about the conditions under which donated tissues will be deemed confidential. By doing so, tissue banking guidelines will be more effective in minimizing potential harms to donors, donor families, as well as to future tissue research and product development. Fourth, tissue banking guidelines and policies should specify what information to address as part of the informed consent process. To do this, tissue banks will already need to be clear about their mission, financial arrangements, and level of confidentiality protections they intend to use. It is only after receiving the required information that the donor (or donor's family) can arrive at an informed decision about whether to provide tissue samples to the facility. Toward this goal, the information to be addressed should be presented in clear and understandable language. These four main requirements are meant to offer general guidance regarding ethical considerations that deserve to be examined. They are neither exhaustive, nor absolute. Rather, they relate to the four factors (commercialization, confidentiality, informed consent, and quality of research) that emerged from the authors' review. Institutional Review Boards, or corresponding bodies, the purview of which is to ensure the protection of research participants, must be involved to aid tissue banks by providing appropriate oversight and monitoring of their activities that relate to research, as well as assistance with specific ethical issues as they arise.

\section{CONCLUSION}

In different hospitals and clinics throughout the country, the legal and ethical questions associated with tissue banks and their function must be identified : these are to provide improved patient care through tissue transplantation; to abolish the trauma and morbidity associated with secondary surgical procedures used to harvest autografts; to reduce prolonged hospitals stays and reduce medical costs; to avoid the sacrifice of the patient's normal structures; to provide unlimited quantities of grafts in suitable sizes and shapes.

Some organizational policies do not address commercialization, while others fail to consider confidentiality and quality of research. However, even in those instances where one of the four factors is recognized by all policies (commercialization, confidentiality, informed consent, and quality of research); there is often a lack of uniformity in its meaning, scope, 
and ethical significance. Until uniform ethical guidelines regulating the storage, distribution, and use of human tissues for research are established, the international transfer of human tissues and multinational research involving industry will not only remain cumbersome but, in many instances, ethically problematic. We propose that in Bangladesh, governments, nongovernmental organizations, and other institutions further collaborate and harmonize policies regarding human tissue.

\section{REFERENCES}

1. Deborah Josefson, "Human Tissue for Sale: What Are the Costs?' Western Journal of Medicine 5 (2000): 302-303.

2. Ted T. Ashburn, Sharon K. Wilson, Barry I. Eisenstein, "Human Tissue Research in the Genomic Era of Medicine: Balancing Individual and Societal Interests,' Archives of Internal Medicine 160 (2000): 3377-3384.

3. Joseph B. Martin, Dennis L. Kasper, "In Whose Best Interest? Breaching the AcademicIndustrial Wall," New England Journal of Medicine 343 (2000): 1646- 1649.

4. Deborah Josefson, "US Hospitals to Ask Patients for Right to Sell their Tissue,' British Medical Journal 321 (2000): 653.

5. Dorothy Nelkin, Lori Andrews, "Homo Economicus: Commercialization of Body Tissue in the Age of Biotechnology,' Hastings Center Report 28 (1998): 30-39.

6. National Organ Transplant Act, 1984. Pub L. No. 98-507, 3 USC 301.

7. Danielle M. Wagner, "Property Rights in the Human Body: The Commercialization of Organ Transplantation and Biotechnology,' Duquesne Law Review, 33 (1995): 931-958.

8. American Association of Tissue Banks, "Ethical Guidelines for Commercial Activities and Advertising,"' (Sept. 11, 1996).

9. Department of Health and Human Services, "Human Cells, Tissues, and Cellular and Tissue-Based Products; Establishment Registration and Listing," Federal Register 66 (Jan. 19, 2001).

10. Curtis Naser and Sheri Alpert, "Genetic Information, Ethics, Ethical Issues in Tissue Banking and Human Subject Research in Stored Tissues,' in: Encyclopedia of Ethical; Legal; and Policy Issues in Biotechnology, eds. T.H. Murray and M.J. Mehlman (New York: John Wiley \& Sons, 2000), p. 365. 